\title{
ISI PIRINGKU DIETARY MEAL PROPORTION ESTIMATOR APPLICATIONS USING SEEFOOD IMAGE SEGMENTATIONS
}

\author{
Fatahah Dwi Ridhani $^{1 *}$, Pritasari ${ }^{2}$, Dyah Retno Anggraini ${ }^{2}$ \\ ${ }^{1}$ Jurusan Teknologi Elektro Medis, Politeknik Kesehatan Kementrian Kesehatan Jakarta II \\ ${ }^{2}$ Jurusan Gizi, Politeknik Kesehatan Kementrian Kesehatan Jakarta II \\ Hang Jebat Blok F3/III, 12120, Jakarta, Indonesia \\ *Email: ridhani@poltekkesjkt2.ac.id
}

Submitted: $11^{\text {th }}$ November 2021; Accepted: $8^{\text {th }}$ December 2021

https://doi.org/10.36525/sanitas.2021.11

\begin{abstract}
Isi Piringku or My Meal Dish Content was a program initiated by the Indonesian ministry of health to promote a healthy daily lifestyle consisting of balanced dietary, enough hydration, active lifestyle, cleanliness and body weight control. The balanced diet meal was supposed to consist of $1 / 3$ of main dish intake, $1 / 3$ of vegetable intake, $1 / 6$ of fruit intake and $1 / 6$ of protein intake every time. This introduces some difficulty that every meal must be measured to align with the dietary guidelines. This study targets estimating the meal diet proportion by its visual cues using smartphone application. While the actual meal content dietary division was weight based, for sake of simplicity the proportion in this study was estimated by each food area which roughly correlates to its volume. Using smartphone cameras in Android 9 Operating Systems and Tensorflow Lite SeeFoods: Mobile Food Segmentation v1.0 module, an application was built to help users estimate their meal balances proportion. The original segmentation criterion was constructed using USDA dietary guidelines and it was reduced to only 4 food groups related to Isi Piringku criterion. Suggestion will be given regarding the segmentation result. The result was that the application was capable of estimating the meal diet proportion and giving suggestions based on the segmentation result. The segmentation accuracy was around $87 \%$ when tested on our prepared dish. On average, the time needed to apply the segmentation process was around 3000 milliseconds on a Snapdragon 835 device.
\end{abstract}

Keywords — isi piringku, tensorflow image segmentation, dietary suggestion application.

This is an open access journal, and articles are distributed under the terms of the Creative Commons AttributionNon Commercial-Share Alike 4.0 License, which allows others to remix, tweak, and build upon the work noncommercially, as long as appropriate credit is given and the new creations are licensed under the identical terms. (C)2021 Sanitas 


\section{INTRODUCTION}

The Indonesia Ministry of Health introduced a balanced dietary guideline (1) under the name "Piring Makanku: Sajian Sekali Makan" or roughly translated as "My Plate Meal: One Time Portion" that later popularized under the name "Isi Piringku" or roughly translated as "my meal (plate) dish content". The name suggests that it may be inspired by the "my plate" program in the United State of America, but different in portion and proportion.(2) While the name suggests only addressing meal dish content, in actuality the guideline was a complete healthy lifestyle guidelines. This guideline or program was succeeding the previous dietary guidelines under the name "4 sehat 5 sempurna" or 4 groups of healthy foods plus group number 5 of perfecting foods.(3) The latest guidelines were promoted to combat obesities of a modern lifestyle (4) but also to prevent stunting that still exist in many areas although there still no correlations found between the program knowledge with the high percentage of stunting cases.(5)

Isi Piringku (6) details about healthy lifestyle that include: 1) Promoting cleanliness by teaching a proper washing hand, that is 20 seconds of washing using soap and a proper technique under flowing clean water; 2) Promoting physical activity in the guise of daily mild or heavy body moving activity or better being a sport activity with no less than 30 minutes of activity every day; 3) Promoting enough hydration by consuming about 8 glasses of clean drinking water daily; 4) Promoting control of body weight by measuring the body weight monthly and keeping it within the proper Body Mass Index (BMI); 5) Promoting the proper balanced meal every time with 4 groups of foods: main or staple food, "lauk pauk" or protein intake food, vegetables and fruits. One meal content could be divided by 2 areas. The first half should consist of $2 / 3$ of carbohydrate or various staple food intake and $1 / 3$ of various meat or plant based protein intake. The other half should consist of $2 / 3$ of various vegetable intake and another $1 / 3$ of various fruit intake; 6) Promoting the reduction of refined sugar, salt and oil intake.

These simplified guidelines were promoted in a hope that the guidelines will be easy enough to be understood by masses and applied while also effective enough to keep a perfect healthy lifestyle. Other types of diet also exist as supplements for a particular case such as reducing energy intake or food combining for overweight persons,(7) or quality diet on Diabetes Melitus (DM) patients.(8) 
Many public health promotion projects had used Isi Piringku in various mediums to introduce the guidelines to the masses. Some use mediums of comics (9)(10) or illustration booklet or video (11) or live demonstration (12) to target elementary school teachers, students and their parents. Another interesting method was by using games (13) or edutainment (14) or addressing groups of maternity mothers.(15) Although it has been more than 7 years since its first inception, the Isi Piringku program has not been adopted widely.

As inferred by the Isi Piringku guidelines, every meal should be measured to have the right portion and proportion. Every food portion should be weighted once or several times and become the daily standard for a portion. This became a burden if there was no easily available method to measure this portion and proportion. Perhaps an easier dietary implementation was using the dietary suggesting or nutrition tracking applications, example like webs based android that follow "Pedoman Umum Gizi Seimbang" (PUGS) guidelines (16) or follow "Tabel Komposisi Pangan Indonesia" (TKPI) guidance (17) or tracking energy intake.(18) The use of mobile apps was for its versatility and readily available device for the masses.(19) At the time of writing, we are having difficulty finding dietary applications that literally use Isi Piringku as its guidelines. Also, all of the dietary suggesting applications require the user to input plenty of data manually before getting any suggestions.

In our opinion, a versatile solution was to be able to measure the proportion of one's meal using image processing, or image segmentation in particular like in the example (20) and (21). Image segmentation judges each pixel of an image whether it belongs to a certain predetermined class. A machine learning platform like Tensorflow (22), provides examples of a readily image segmentation implementation. There is an available model that provides food image segmentation based on USDA (United States Department of Agriculture) dietary guidelines.(23) This provided a groundwork for a modification to use Isi Piringku criterion for the image segmentation implementation.

We proposed an implementation of measuring one's meal proportion following Isi Piringku guidelines using one's smartphone. The meal image was captured using a mobile phone camera and proceeded for analysis using ready to use SeeFood v.1.0 image segmentation from Google Brain team. Once the proportion was measured in percentage, later the mobile 
application will suggest the portion that should be added or subtracted following the Isi Piringku guideline as illustrated in figure 1. This should improve the adoption of Isi Piringku dietary guidelines for the smartphone users by minimizing manual input.

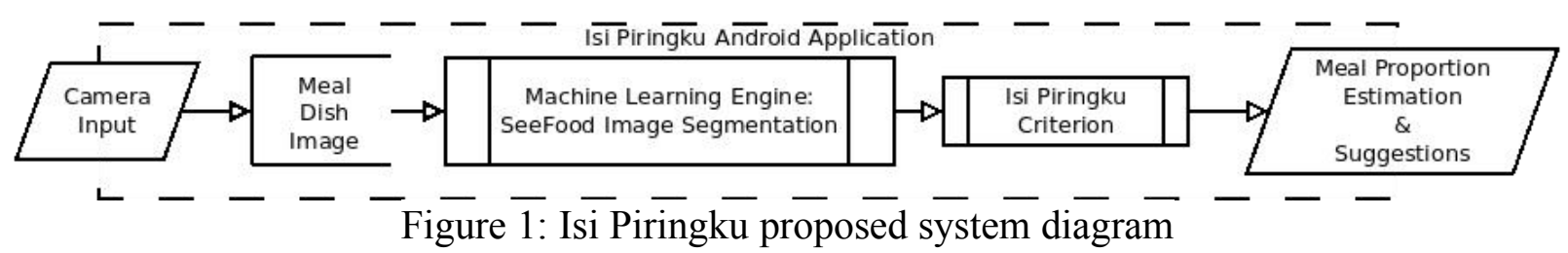

\section{RESEARCH METHOD}

Our work was the following: it was to implement SeeFood module for food image segmentation and interpret the outputs using a particular criterion, that is Isi Piringku food groups, on a mobile phone application for meal proportion suggestions. The original requirement for the food proportions was weight based, but for the sake of simplicity and proof of the concept, it will be based on total area only that was assumed to be in correlation with its volume as the image captured by the camera was in 2 (two) dimensional flat planes. The proportion was estimated in percentage, and a suggestion provided based on the result for the user to add or subtract the meal to have a balanced proportions. This provides crude measurement tools for estimating meal proportion. An Android application was built using the Android Studio Integrated Development Environment (IDE), and the built results will be explained in terms of usage, the accuracy of image segmentation using the tested food images captured, and the resulting suggestions, and all of its current shortcomings. This is more of qualitative proof of a concept work research types. The data involved and results was roughly an estimation even though it was quantized and it follows the characteristics of the groundwork food image segmentation platform that was based.

The application software built was tested on an Android Pie Operating System (OS) or number 9.0 OS official version phone that is a Docomo Sony Xperia XZ1 Compact models with Qualcomm MSM8998 Snapdragon 835 System on a Chip (SOC), 4 Gigabytes of RAM, and using the back camera systems. The Exmor RS back illuminated Sony built camera has 19 Mega 
Picture Elements (Pixel) that was the highest resolution camera at its time,(24) focal length of $\mathrm{f} / 2.0$ or equivalent with $25 \mathrm{~mm}$ Sony built lens that considered as wide range view lens, with the sensor size of $1 / 2.3$ " that translates to $1.22 \mu \mathrm{m}$ camera pixel individual size, a predictive Phase Detection Auto Focus (PDAF) plus a laser auto focus to help the focussing the lens assembly especially for close range taking picture situation like in the food image capturing. The Snapdragon 835 solution SOC consist of an octa-core Central Processing Unit (CPU) with dual cluster processor that is 4 Kryo cores running at $2.45 \mathrm{GHz}$ and another 4 Kryo cores running at 1.9 GHz Kryo, plus a Graphic Processing Unit (GPU) of Adreno 540. At the time of writing, this SOC was at the rank of $53^{\text {th }}$ with a performance benchmark at $43 \%$ processing power compared to the top available SOC.(25) Kryo cores is a custom ARM A73 processor that implements the ARMv8-A 64-bit instruction set equipped with 2 MB level 2 cache for the performance cluster and $1 \mathrm{MB}$ level 2 cache for efficiency cluster built on Samsung $10 \mathrm{~nm}$ Liquid-Phase Epitaxy (LPE) process. The SOC has an Adreno 540 that is a quad-core GPU running at maximum of 710 or $670 \mathrm{MHz}$ with 384 Arithmetic and Logic Units (ALU)s, 16 Texture Mapping Units (TMU)s and 12 Render Output Units (ROP)s that handle a relatively small 1280x720 pixel screen. Qualcomm Spectra 180 Image Signal Processing (ISP) with Dual 14-bit ISPs was responsible for the handling and processing.(26) This should reduce the noise and improve the quality of the captured image. The internal storage usage was around $45 \%$ from the 32 GB storage provided and average of 2.2 GB out of 3.9 GB RAM memory used. The OS Kernel version was 4.4.148-perf + with no battery saving scheme. Background applications were suppressed from being active as much as possible with only core services running. Overall, this system should provide an adequate platform for an image segmentation implementation.

As mentioned above, the image segmentation module used was from Tensorflow platform, a free and open-source software library. There were several other food image segmentation model architectures mentioned (27) but this requires one to train and evaluate their own models. Currently, food image segmentation was lacking due to low numbers of high quality dataset.(28) The Google Brain team developed the SeeFood library initially for internal use in research and production. Although, the model accuracy details were not provided. A Lite version was introduced for mobile development and ready to use. On Android devices mobile GPU inference engine with OpenGL ES 3.1 Compute Shaders was used.(29) The machine 
learning module model used was a TensorFlow Google developed model under the name Seefood: Mobile Food Segmenter version 1.0 that was updated on 5th november 2021 (abbreviated as Seefood 1.0). This was a food semantic segmentation model that parses an input dish image into regions of 26 food groups. The Google team constructed the label map and based the map from USDA dietary guidelines. The team used lists of popular dishes in Google Lens and Maps. This means that the dataset base for the models was a proprietary set. The architecture adopted was the neural network architecture of DeepLab-V3 with the backbone of MobileNet-V2 for its semantic segmentation model. The developer suggests that this model is suitable for making a coarse-grained guess of the major ingredients of the input food dish.(23) Unfortunately, we failed to find the benchmark for this module compared to other food image segmentation, so we performed a small scale test with our available base class foods at our food labs.

The number of labels of the segmentation food group of Seefood 1.0 was 26 (twenty six). It will be further classified down to 4 (four) class regarding Isi Piringku criterion. Starting with the non food segment, three of the labels are non food: "background", "food container" and "dining tools". These three will be neglected as it was not contributing the proportion of the captured meal image. The Isi Piringku "Makanan Pokok" class is consist mostly from locally popular main dish with ideal proportion of $33.33 \%$ overall. Seefood 1.0 available labels that correspond with this classification was set as follow: "starch/grains: noodles/pasta", "starch/grains: rice/grains/cereals", "starch/grains: baked_goods", "starch/grains: starchy_vegetables", "starch/grains: other", "snack", “sweet/desserts", "other_food". Three later labels usually consist of foods that were heavy in calories and made from carbohydrate sources, at least here in Indonesia. Therefore it was safe to assume these labels under "Makanan Pokok". The next class of Isi Piringku was "Lauk Pauk" which consisted mainly of protein intake from animal sources and plant sources. Dairy also belongs to this category. The ideal proportion for "Lauk Pauk" is $16.66 \%$. For class of "Lauk Pauk", it was decided to consist of following label: "protein: eggs", "protein: beans/nuts", "protein: meat", "protein: poultry", "protein: seafood", "dairy", "herbs/spices", "fats/oils/sauces", "soups/stews". Similar to the above argument, in Indonesia usually soups, stews, herbs, spices, fat, oils and various sauces were found almost exclusively within the "Lauk Pauk" kind of menu. If it was detected in a meal, it will be added to 
the volume of "Lauk Pauk" class. The class of vegetables or "Sayur-Sayuran" with an ideal proportion of $33.33 \%$ consist of labels: "vegetables: stem_vegetables", "vegetables: leafy_greens", "vegetables: non-starchy_roots, ", "vegetables: other". The "Buah-Buahan" class uses solely the "fruits" label. The ideal proportion for "Buah-Buahan" was $16.66 \%$. It was summarized and visualized in table 1. There was a label in Seefood 1.0 that was neglected as it was outside of Isi Piringku class that was: "beverages".

Table 1: SeeFood 1.0 labels to Isi Piringku classification

SeeFood 1.0 labels Isi Piringku class Ideal

Proportion

starch/grains: noodles/pasta

starch/grains: rice/grains/cereals

starch/grains: baked_goods

starch/grains: starchy_vegetables

starch/grains: other

Makanan Pokok $\quad 33.33 \%$

snack

sweet/desserts

other_food

protein: eggs

protein: beans/nuts

protein: meat

protein: poultry

protein: seafood

Lauk Pauk

$16.66 \%$

dairy

herbs/spices

fats/oils/sauces

soups/stews

vegetables: stem_vegetables

vegetables: leafy_greens

vegetables: non-starchy roots

vegetables: other

\begin{tabular}{ccc}
\hline fruits & Buah-Buahan & $16.66 \%$ \\
\hline $\begin{array}{c}\text { beverages } \\
\text { background } \\
\text { food container } \\
\text { dining tools }\end{array}$ & (not used) & - \\
\hline
\end{tabular}

Result from the image segmentation process was a list label that corresponded to each of 
the food groups. A suggestion message was given to the screen to increase those portions of "Lauk Pauk", "Sayur-Sayuran" dan "Buah-Buahan" if each is lower than $80 \%$ of its ideal proportions or equal to less than $13 \%, 26 \%$ and $13 \%$ respectively. This is chosen as these food groups were usually lacking among Indonesian diet patterns.(30) On the contrary, for the "Makanan Pokok" class, the default suggestion was to lower the portion size if it is greater than $120 \%$ of its ideal proportions or greater than $40 \%$ overall. This was regarding the result of a survey conducted on the waste of rice found in the study.(31) Otherwise, no suggestion was given.

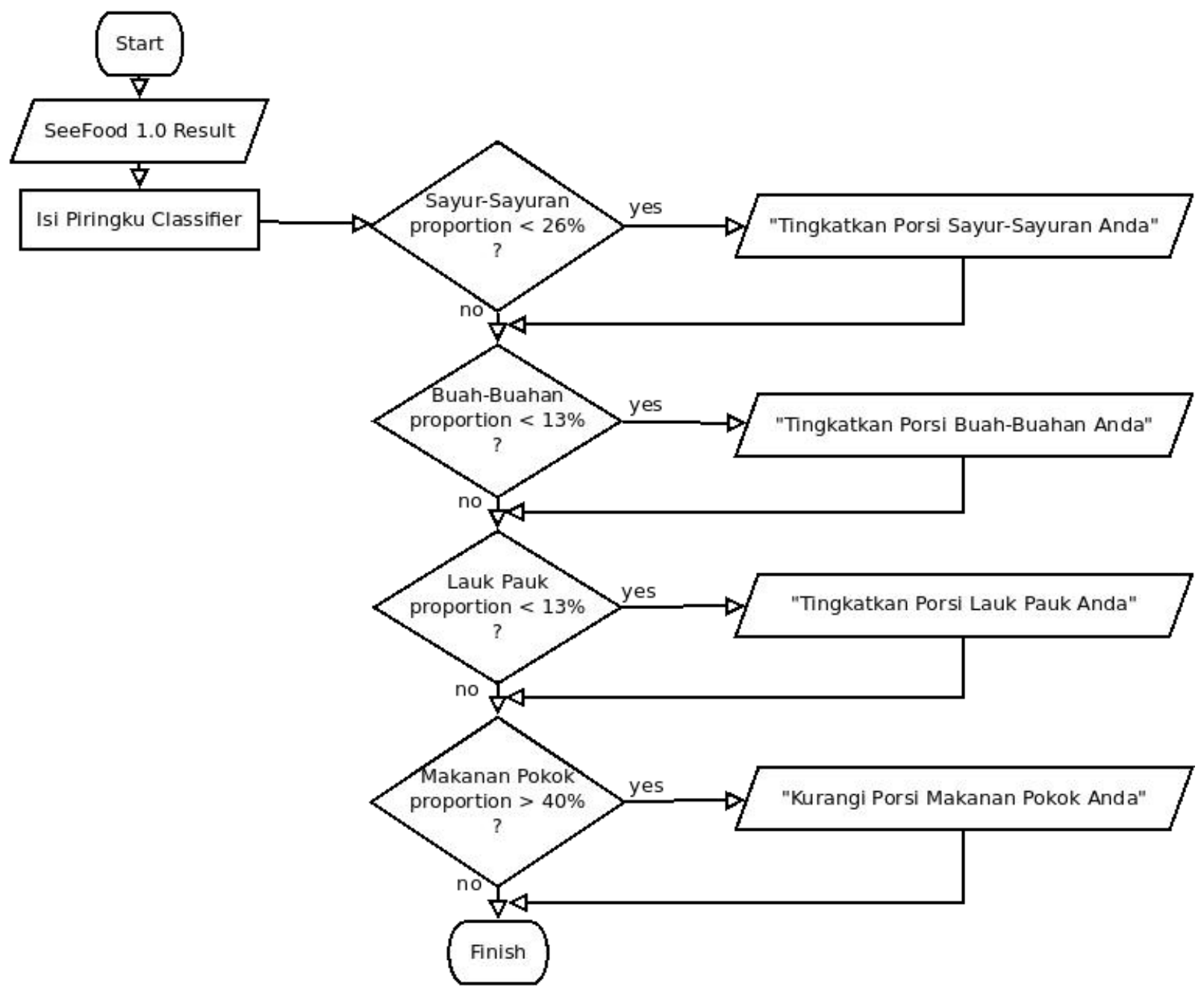

Figure 2: Isi Piringku suggestion decision making flow diagram

The SeeFood 1.0 accepts RGB images with the maximum size of 513x513. Anything beyond this size will be scaled down. It will output segmentation masks and a related file named "labelfile.txt" containing labels of classes that the model can recognize. Each mask containing 
pixel information represents a particular label that later counts as percentage of image. Four non used labels were subtracted from the number of total pixels, so $100 \%$ represent the presence of food only. The class proportion was counted as:

percentage_of_class $[i]=n \_c l a s s \_p i x e l[i] /\left(N \_O R I G I N A L \_P I X E L-n \_n o t \_u s e d \_p i x e l\right) * 100 \%$

The calculation result will be used as evaluating value for the inference process. The decision making flow diagram was illustrated in figure 2 .

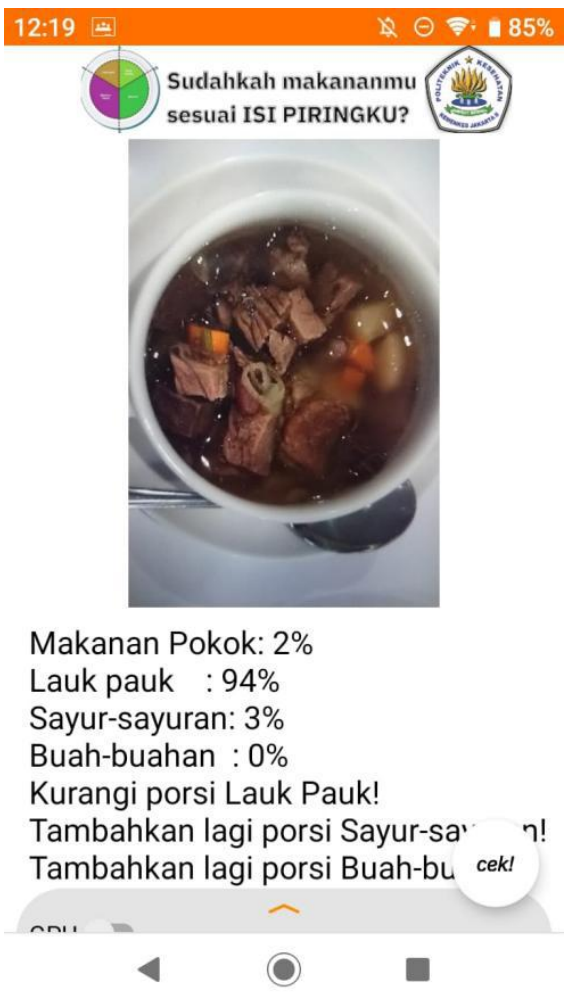

Figure 3: "Pengukur Isi Piringku" Application user interface layouts

The Android application layout was shown on figure 3. A label, camera viewfinder, a capture button and status panel. Once the capture button is pressed, it grabs the current frame content of the viewfinder, processes it and reports its result segmentation. Input image size was: 480x640. Number of threads used was 4 . The percentage of a particular food segment correlated with its label was by calculating the mask pixel number. The application takes the name of "Pengukur Isi Piringku". This layout was scaled to fit the 1280x720 resolution size of Sony Xperia XZ1 Compact screen. 
For testing the application, several meal dish objects were used with emphasis on extremities. The meal dishes that locals usually label as: "lauk pauk", "sayur-sayuran", buahbuahan", "nasi", and a single portion commonly served in daily meals. We tested and recorded the response of the application. Figure 4: shows some examples of the meal dishes used as testers out of the 80 varieties of meals.

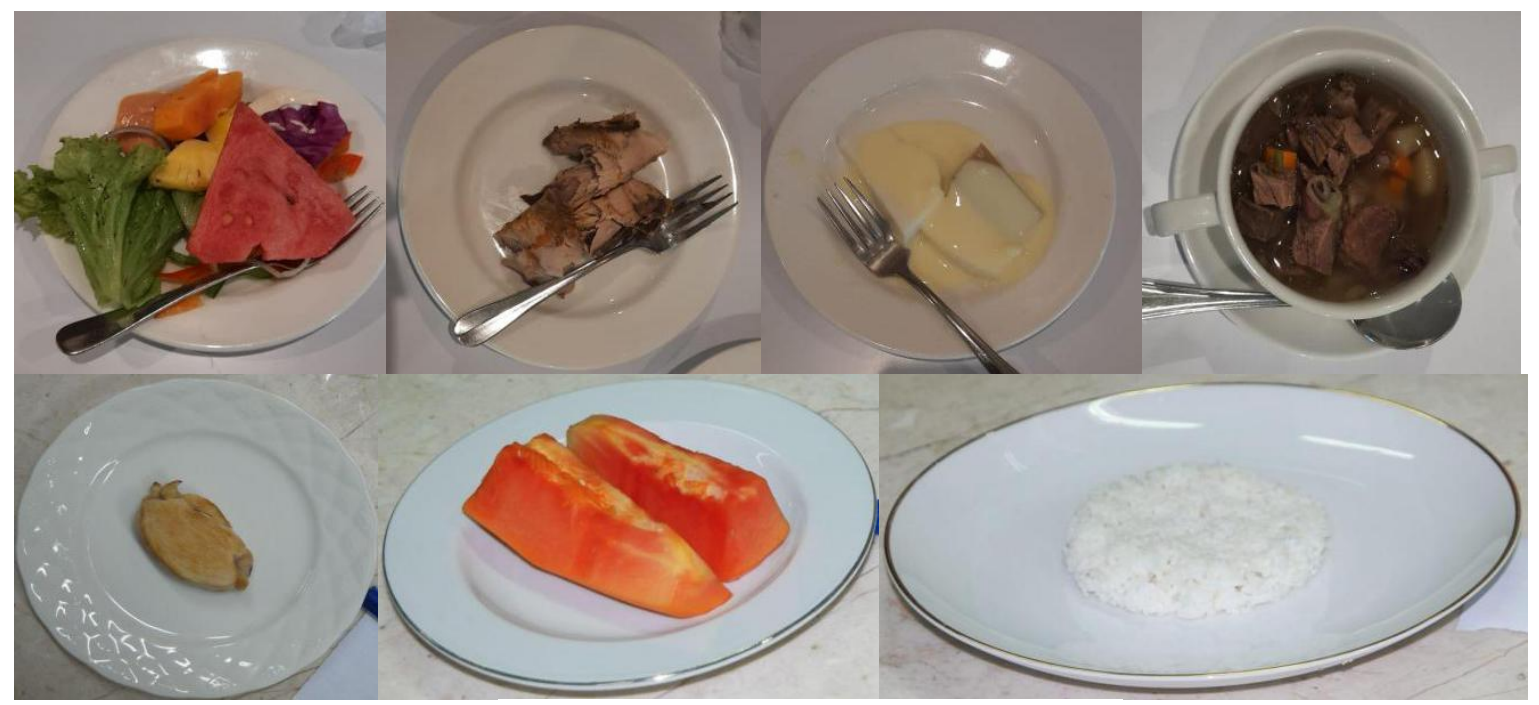

Figure 4: Meal dish as tester example

\section{RESULT AND DISCUSSION}

The former image was a captured screen of the "Pengukur Isi Piringku" as shown by figure 3, with average measured luminance around 82-92 lux using onboard Sony Xperia XZ1 Compact light sensor. The segmentation done averaging at less than $3000 \mathrm{~ms}$. The suggestions were shown in regard to the result of the segmentation process. Shown at the screen, an estimation of each food group in percentage. This proves that the intended mechanism worked. Tabel 2 detailed the results data on suggestions resulting from the tested applications.

If the inner process was shown as breakdown of result from segmentation layers, it will look similar to the in figure 6 . The images captured by the smartphone camera were processed by the inference method of SeeFood 1.0 segmentation module. The result was a mask bitmap with color information related to each identified food group that was labeled in a label map variable. 
The portion percentage was measured by counting the number of pixels that belong to the label criteria.

Tabel 2: Suggestion result based on the meal dishes tested

\begin{tabular}{cl}
\hline Labeled Tested Meal Content & All suggestion result \\
\hline Lauk Pauk & $\begin{array}{c}\text { "Tambah lagi Sayur-sayuran" } \\
\text { "Tambah lagi Buah-buahan" }\end{array}$ \\
\hline Buah-Buahan & $\begin{array}{c}\text { "Tambah lagi Sayur-sayuran" } \\
\text { "Tambah lagi Lauk-Pauk" }\end{array}$ \\
\hline Sayur-sayuran & "Tambah lagi Buah-buahan" \\
\hline Nasi & $\begin{array}{c}\text { "Tambah lagi Sayur-sayuran" } \\
\text { "Tambah lagi Buah-buahan" } \\
\text { "Kurangi Makanan Pokok" }\end{array}$ \\
\hline Single portion of daily meal & "Tambah lagi Sayur-sayuran" \\
& "Tambah lagi Buah-buahan" \\
& "Kurangi Makanan Pokok" \\
\hline
\end{tabular}
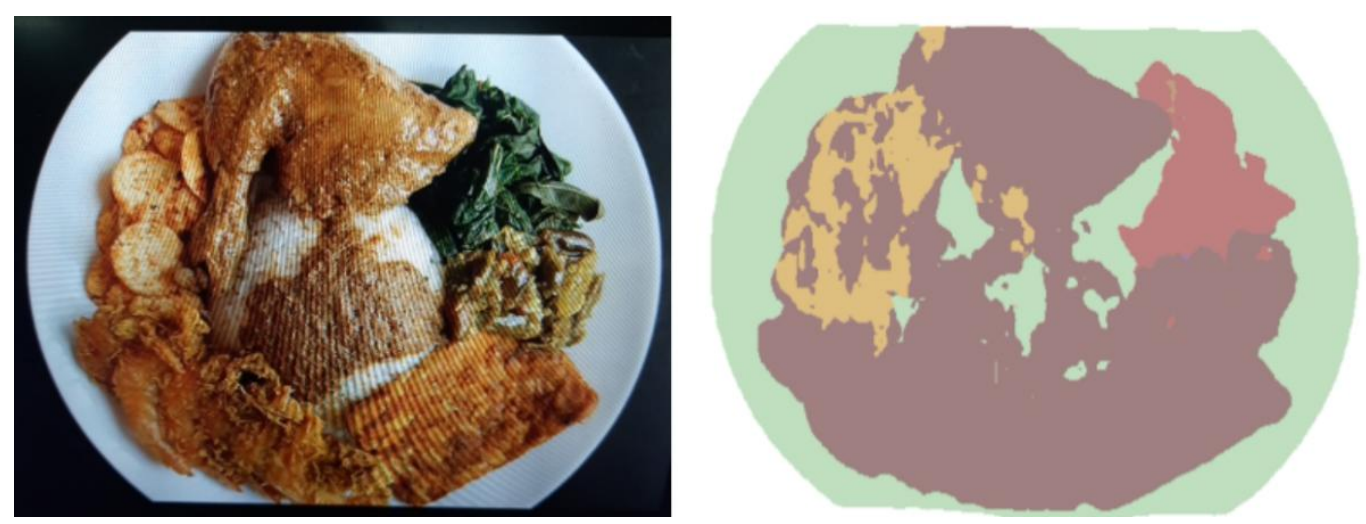

Figure 6: example of image captured and segmented by SeeFood

There were still hit and miss situations, some pixel that humans recognized as a certain type of food was labeled as something else. This is especially prominent in meals with mixed herb, spices, and thick gravy or starch coated fried foods that were falsely labelled. The details of segmentation results on our prepared dish were shown at table 3 with the averaged accuracy level at $87 \%$. For the "nasi" type of meal, the labeled accuracy was close to $100 \%$. "Lauk pauk" type of meal labeled accuracy was lower at $93 \%$ with some of the labeled pixels mistaken as either "sayur-sayuran" or "buah-buahan" but never "makanan pokok". "Sayur-sayuran" was 
either mistaken as "container" or "makanan pokok" with accuracy around 86\%. "Buah-buahan" was around $59 \%$. The accuracy of segmentation was different in a complete meal, in that "nasi" was mostly labeled as "container", especially on gravy and spice heavy dishes. These results cannot be taken as a complete benchmark of the SeeFood model and it is beyond the scope of this work as it is related to the TensorFlow segmentation engine and the SeeFood 1.0 model used. We used it as it is and did not perform training and build its model. As a Isi Piringku dietary estimation and suggestion provider, this application has worked and achieved its objective.

Tabel 3: Average error rate result of SeeFood image segmentation

\begin{tabular}{cc}
\hline Labeled Tested Meal Content & Error rate \\
\hline Lauk Pauk (40 dish) & $93 \%$ \\
\hline Buah-Buahan (10 dish) & $59 \%$ \\
\hline Sayur-sayuran (10 dish) & $86 \%$ \\
\hline Nasi (10 dish) & $100 \%$ \\
\hline Single portion of daily meal (10 dish) & $79 \%$ \\
\hline
\end{tabular}

\section{CONCLUSION}

The proof of concept was satisfied that it was possible to use the available image segmentation TensorFlow Lite module with SeeFood: Mobile Food Segmenter version 1.0 model to be used as a rough estimator for meal dietary proportion using Isi Piringku criterion. The estimation was done in around 3 seconds using Android Pie OS on Sony Xperia XZ1 Compact and it provides the intended suggestions. This should add to the easiness and versatility when estimating one's meal diet in accordance with the Isi Piringku dietary guide. The work objectives were achieved.

The accuracy of the given food segmentation was subject to its machine learning model and this should be addressed in future works. This segmentation result should refer to the characteristics of its module that it was based on hence the result acquired in this work cannot be 
taken as an exact conclusion. Further works can also address the relation between areas of particular food recognized to correlate its volume with its weight, estimating its size, calorific value, micro nutrients and many nutrition aspects related. It would be interesting if the method applied in the form of Augmented Reality with no user manual input.

\section{ACKNOWLEDGMENTS}

We gratefully acknowledge the Pusat Penelitian dan Pengabdian Masyarakat Poltekkes Kemenkes Jakarta II for the grant provided for this initial research.

\section{REFERENCES}

1. Permenkes no.14 tahun 2014 [Internet]. Jakarta: Biro Hukum dan Organisasi Kementerian Kesehatan Republik Indonesia; c2014 [cited 2021 November 1]. Available from:

http://hukor.kemkes.go.id/uploads/produk_hukum/PMK\%20No.\%2041\%20ttg\%20Pedo man\%20Gizi\%20Seimbang.pdf

2. Anjarsari I, Listyaningsih P, Linawati R, Dewi RS. Peningkatan Kesadaran Diri Pada Makanan Bergizi Melalui Metode "Isi Piringku" Pada Anak Usia 4-5 Tahun Di TK PGRI Payungan Kecamatan Kaliwungu Kabupaten Semarang. Sentra Cendekia. 2021 Jul 30;2(2):56-62.

3. Ardiaria M, Subagio HW, Puruhita N. SOSIALISASI PRINSIP DAN PESAN GIZI SEIMBANG SEBAGAI PENGGANTI PROGRAM EMPAT SEHAT LIMA SEMPURNA. JNH (Journal of Nutrition and Health). 2020;8(1):51-6.

4. p2ptm.kemkes.go.id [Internet]. Jakarta: Direktorat Jenderal Pencegahan Dan Pengendalian Penyakit Kementerian Kesehatan Republik Indonesia; c2018 [cited 2021 November 1]. Available from: http://p2ptm.kemkes.go.id/infographicp2ptm/obesitas/page/14/isi-piringku-sekali-makan

5. Devriany A, Wulandari DA. Hubungan Pengetahuan Ibu Tentang "Isi Piringku" dengan Kejadian Stunting Anak Balita Usia 12-59 Bulan. Jurnal Kesehatan. 2021 Apr 29;12(1):17-24.

6. kesmas.kemkes.go.id [Internet]. Jakarta: Direktorat Jenderal Kesehatan Masyarakat 
Kementerian Kesehatan Republik Indonesia; c2018 [cited 2021 November 1]. Available from: $\quad$ https://kesmas.kemkes.go.id/assets/uploads/contents/others/LEAFLET-ISIPIRINGKU-ilovepdf-compressed_1011.pdf

7. Damayanti D, Pritasari P, Prayitno N, Ngadiarti I, Zulfianto N. Comparing The Effect Between Energy Reducing Diet And Food Combining On Body Weight Change Among Overweight Adult. SANITAS [Internet]. 4Jun.2020 [cited 6Nov.2021];11(1):1-4.

8. Pertiwi R, Yuliantin E, Wahyudi A. The Influence Of Diet On Quality Nutrition Counselling Patients Of Type 2 Diabetes Mellitus In Poly Disease In The RSUD Dr.M. Yunus Bengkulu 2018. SANITAS [Internet]. 1Dec.2018 [cited 6Nov.2021];9(2):83-2.

9. Darni J, Agustina E. Pengaruh Komik Isi Piringku terhadap Asupan Karbohidrat dan Protein pada Anak Gizi Lebih. Jurnal Gizi Prima (Prime Nutrition Journal). 2020 Apr 29;5(1):16-9.

10. Cendikia ZA. PENGARUH PENGGUNAAN MEDIA KOMIK "ISI PIRINGKU" SEBAGAI MEDIA EDUKASI TERHADAP PENGETAHUAN DAN SIKAP TENTANG ISI PIRINGKU PADA SISWA SEKOLAH DASAR [Doctoral dissertation]. Yogyakarta: Poltekkes Kemenkes Yogyakarta; 2020

11. Fitriani A. EDUKASI ISI PIRINGKU KEPADA GURU DAN ORANGTUA UNTUK MENINGKATKAN KERAGAMAN MAKANAN DARI ASPEK SAYUR DAN BUAH PADA SISWA SD DI JAKARTA. JMM (Jurnal Masyarakat Mandiri). 2021 Oct 25;5(5):2755-69.

12. Mardiana M, Yuniarti H, Susanto E. IMPROVEMENT OF BALANCED NUTRITIONAL KNOWLEDGE AND SKILLS THROUGH THE DEMONSTRATION OF ISI PIRINGKU IN BASIC SCHOOL CHILDREN. JCES (Journal of Character Education Society). 2021 Apr 24;4(2):495-503.

13. Indradewi, IR. PENGARUH PEMBERIAN EDUKASI GIZI MENGGUNAKAN MEDIA PERMAIAN MONOPOLI TERHADAP PENGETAHUAN DAN SIKAP TENTANG ISI PIRINGKU PADA SISWA SEKOLAH DASAR [Skripsi D IV]. Semarang: Poltekkes Kemenkes Semarang; 2020

14. Kurniasari R, Rahmatunnisa R. PENDIDIKAN GIZI MENGGUNAKAN MEDIA NUTRIEDUTAINMENT TERHADAP PENGETAHUAN GIZI SEIMBANG ANAK SEKOLAH DASAR. Jurnal Gizi dan Kuliner. 2020;1(2):33-40. 
15. Rahmanindar N, Zulfiana E, Harnawati RA. Pembentukan Kelompok Ibu Siaga Stunting dalam Pemulihan Balita Gizi Buruk Menggunakan Program Isi Piringku. Jurnal PkM (Pengabdian kepada Masyarakat). 2020 Dec 30;3(4):372-7.

16. Pamungkas GA, Isnanto RR, Martono KT. Pembuatan Aplikasi Panduan Gizi Seimbang Berbasis Android Dengan Menggunakan Metode Backward Chaining. Jurnal Teknologi dan Sistem Komputer. 2016 Apr 23;4(2):369-79.

17. Apriningrum N, Carudin C, Andriani E. RANCANG BANGUN APLIKASI GIZI BERBASIS ANDROID BERDASARKAN TABEL KOMPOSISI PANGAN INDONESIA (TKPI. Sistemasi: Jurnal Sistem Informasi. 2020 Sep 27;9(3):567-85.

18. Shinozaki N, Murakami K. Evaluation of the Ability of Diet-Tracking Mobile Applications to Estimate Energy and Nutrient Intake in Japan. Nutrients. 2020 Nov;12(11):3327.

19. Hidayati R, Ahniar N, Lestari G, Hendryani A, Hakim F. Self-monitoring of Glucose With A Non-invasive Method Using Near Infrared Sensor. SANITAS [Internet]. 10Dec.2020 [cited 6Nov.2021];11(2):111-2.

20. Freitas CN, Cordeiro FR, Macario V. MyFood: A Food Segmentation and Classification System to Aid Nutritional Monitoring. In2020 33rd SIBGRAPI Conference on Graphics, Patterns and Images (SIBGRAPI) 2020 Nov 7 (pp. 234-239). IEEE.

21. Poply P. An Instance Segmentation approach to Food Calorie Estimation using Mask RCNN. InProceedings of the 2020 3rd International Conference on Signal Processing and Machine Learning 2020 Oct 22 (pp. 73-78).

22. Abadi M, Barham P, Chen J, Chen Z, Davis A, Dean J, Devin M, Ghemawat S, Irving G, Isard M, Kudlur M. Tensorflow: A system for large-scale machine learning. In12th \{USENIX\} symposium on operating systems design and implementation (\{OSDI\} 16) 2016 (pp. 265-283).

23. Google [Internet]. TensorFlow Hub; c2021 [updated 2021 November 05; cited 2021 November $06]$. Available from:https://thub.dev/google/seefood/segmenter/mobile food segmenter V1/1

24. Davies, Amy [Internet]. Photography Blog: Sony Xperia XZ1 Review; 2017 [cited 2021 November 06]. Available from: https://www.photographyblog.com/reviews/sony xperia_xz1_review 
25. nanoreview.net [Internet]. Smartphone Processors Ranking; c2021 [updated 2021 July; cited 2021 November 06]. Available from: https://nanoreview.net/en/soc-list/rating

26. Qualcomm [Internet]. San Diego: Snapdragon 835 Mobile Platform; c2021 [cited 2021 November 06]. Available from: https://www.qualcomm.com/products/snapdragon-835mobile-platform

27. Aslan S, Ciocca G, Mazzini D, Schettini R. Benchmarking algorithms for food localization and semantic segmentation. International Journal of Machine Learning and Cybernetics. 2020 Dec;11(12):2827-47.

28. Wu X, Fu X, Liu Y, Lim EP, Hoi SC, Sun Q. A Large-Scale Benchmark for Food Image Segmentation. arXiv preprint arXiv:2105.05409. 2021 May 12.

29. TensorFlow team [Internet]. TensorFlow Lite Now Faster with Mobile GPUs; 2019 January 17 [cited 2021 November 06]. Available from: https://medium.com/tensorflow/tensorflow-lite-now-faster-with-mobile-gpus-developerpreview-e15797e6dee7

30. Hermina H, Prihatini S. Gambaran konsumsi sayur dan buah penduduk Indonesia dalam konteks gizi seimbang: analisis lanjut survei konsumsi makanan individu (SKMI) 2014. Indonesian Bulletin of Health Research. 2016;44(3):205-18.

31. Anriany D, Martianto D. Estimasi sisa nasi konsumen di beberapa jenis rumah makan di Kota Bogor. Jurnal Gizi dan Pangan. 2013 Nov 29;8(1):33-8. 